as well face the fact that it will not be enough to have a mechanism for keeping the peace which a few scholars and statesmen think well of. If it is really to work, it must have such widespread acceptance and confidence that peoples as well as philosophers support it as a thoroughly honorable and reasonably hopeful alternative to war. ${ }^{20}$

Doubtful of the utility of codification of international law until the world had many more shared experiences and values in dealing with international disputes by legal means, ${ }^{30}$ he felt that:

we should take advantage of every opportunity to deal with international controversies by the adjudicative or arbitral techniques. In this way we will enlarge and expand the world's experience in using these orderly and reasonable processes, fashion an increasing body of decisional and customary international law, and encourage the lawabiding habit among nations. ${ }^{31}$

There may be room for much difference of opinion as to the validity of some of the views expressed by Mr. Justice Jackson, but in the main they are sound and necessary for making real progress in international law. He was only too aware that the lasting value of the Nürnberg principles will depend far less on the ready acceptance given them by the United Nations General Assembly than on the use made of them in the future. Most of us will agree with his belief that:

Those who best know the deficiencies of international law are those who also know the diversity and permanence of its accomplishments and its indispensability to a world that plans to live in peace. ${ }^{32}$

WM. W. BIshop, JR.

\title{
CHARLES WARREN
}

Charles Warren was born March 9, 1868, and died August 16, 1954, at his home in Washington at the age of 86. A native Bostonian of pure Colonial ancestry, a graduate of Harvard, a student at the Harvard Law School for two years (obtaining a degree of A.M.), Mr. Warren came to be early marked as an author and historian. His career may be divided roughly into several more or less distinct phases. During the first phase up to 1914, while he was engaged in the practice of law in Boston, he tried his hand at a novel, The Girl and the Governor (1900), and a poem delivered at the dedication of the Harvard Union in 1901. But his penchant for historical writing was by that time distinctly budding. Besides various legal papers and historical notes in current law reviews, he published a two-volume work on The Harvard Law School and Early Legal Conditions in America (1909), and A History of the American Bar, Colonial and Federal, to the Year 1860 (1911). ${ }^{1}$

29 Address of April 13, 1945, loc. cit. (footnote 4 above), at p. 12.

30 Address before American Society of International Law, April 26, 1952. Proceedings, 1952, p. 196, at p. 201. See also footnote 27 above.

31 Loc. cit. (footnote 19 above), at p. 158.

82 Address of April 13, 1945, loc. cit. (footnote 4 above), at p. 11.

1 The writer is indebted to the kindness of Mrs. Cleada N. Horne, Mr. Warren's secretary for over 35 years, for making available certain data for this paper. 
A second phase, which might be called the "War and Neutrality" phase, from his appointment as Assistant Attorney General of the United States to about 1920, covers his incumbency in the Department of Justice and the war period. In this phase he was charged with enforcing our neutrality laws and obligations and prosecuting the hostile activities of belligerent agents in the United States, and his writings naturally grew out of official duties. As he found there had been practically no neutrality legislation since 1838 and but a few criminal laws appropriate to curbing these activities, he drafted, by direction of the Attorney General, 18 protective laws which were submitted by the latter to Congress in June, 1916, but were not presently enacted. After the United States entered the war, many of these provisions were incorporated in the so-called Espionage Act of June 15, 1917, which was really a neutrality law, and in the Sabotage Act of 1918. He was also instrumental (in connection with the Department of State) in drafting the Trading With the Enemy Act of July 6, 1917, which was largely based on the British enactments.

In 1915, soon after he came to Washington, Mr. Warren joined this Society and ever since had been a loyal and helpful member. He sat on the Executive Council and various committees, participated in the annual meetings, and was made an Honorary Vice President in 1936. His remarks and comments in the discussions of legal questions were penetrating and ranged over a broad field, but had particular reference to the law of war and neutrality. His only contribution in this period to the Journal was a review of Huberich's book on Trading With the Enemy (1918), which he praised highly as describing the new policy of the United States for the treatment of enemy property, namely, conscripting it to fight the adversary while conserving it in safe investment.

Now came the third and crowning phase of his career from 1920 to 1932. This was the flowering period of his work. His great and abiding love was the history of the Constitution of the United States as interpreted by the United States Supreme Court. Fortunately, he had the time and circumstance to devote himself to his chosen field. He was a profound scholar and a meticulous historian as well as an interesting writer. These all combined in this period to produce the great works which made him famous. The chief work was The Supreme Court in the History of the United States (three volumes, 1922, rev. 2 volumes 1926), which won the Pulitzer Prize for History in 1923, and established him a secure and enviable reputation as an authority on the Constitution and the Supreme Court. It was regarded as the best account of the Court's part in maintaining the Constitution and in shaping the destiny of the growing nation. With unbelievable patience and industry he examined the contemporary newspapers, correspondence, manuscripts, documents and histories of the time in order to determine the influences surrounding the Court and the public reaction to its important decisions. It has been cited many times as authority in the decisions of the Court. The first words in the Preface are: "This is not a law book. It is a narrative of a section of our national history connected with the Supreme Court and is written for laymen and 
lawyers alike." It is an effort "to revivify the important cases and to picture the Court itself from year to year in its contemporary setting."

This work was followed in 1925 by Congress, the Constitution, and the Supreme Court (rev. 1935), which was really a supplement to the former work. Here the author depicts the efforts of Congress to break out of the straight-jacket imposed by the Constitution and its guardian, the Supreme Court. Then in 1928 came The Making of the Constitution (rev. 1937), in which the author takes the reader day by day through the proceedings of the Constitutional Convention during the hot months of 1787. From the debates set down in Madison's Notes and later comments of the various delegates, he made a running account of what went on in the Convention, the conflicts of views and the underlying reasons for each provision adopted.

Then honors fell about him on all sides. The Supreme Court appointed him special master to hold hearings in the cases of New Mexico v. Texas (1924), Utah v. United States (1929), Texas v. New Mexico (1936). President Roosevelt appointed him the American member of the Arbitral Tribunal in the Trail Smelter case between the United States and Canada, 1929, and the American member of the Conciliation Commission between the United States and Hungary, 1939. Columbia University gave him an honorary LL.D. in 1933. He was elected to the Harvard Board of Overseers 1934 (like his father and great-great-grandfather) and President of the Harvard Alumni Association, 1941.

The fourth phase, from about 1933 to 1936, when a second war threatened Europe, was a flareback to the second phase in World War I and signified his earnest attempts to keep the United States out of the coming conflagration by restricting the area of conflict with belligerents over socalled neutral rights. This is his most fruitful period in the annals of this Society. Having been in the Government in World War I, he naturally formed definite ideas about the neutral attitude of the United States in a future war. Out of this experience came his first paper before the Society entitled "What are the Rights of Neutrals Now, in Practice?" (1933). The theme was that, however the legal rights of neutrals stood in 1914, there had been nothing done to clear up the contest over them in the last war on account of the innovations of modern warfare: "There are no rules or laws of naval warfare affecting neutral trade as to which the Great Powers are in agreement."

In view of this doubtful status of neutral rights, Mr. Warren, in an article in Foreign Affairs (April, 1934) on the "Troubles of a Neutral," advocated that something should be done to avoid another embroilment over neutral rights. Among other things, he contended in substance that the President should, at the outset of war negotiate with the belligerents a modus vivendi of concessions for neutral trade, or failing this, he had various alternatives of which one was to declare that neutrals have no rights, another was not to irritate the belligerents by pressing violations of neutral rights until the conclusion of the war.

His first article in the Journal was entitled "Belligerent Aircraft, Neutral Trade and Unpreparedness" (1935). In this he deplored the 
fact that little or nothing had been written by jurists on the problems of neutral trade in the light of armed merchantmen, submarines or aircraft, and that no effective action had been taken by nations to settle these legal questions which were sure to irritate relations of neutrals and belligerents in the future. At the same time, he proposed in a letter to the Washington Post of April 26, 1935, a series of nine suggestions as to what should be done to fill the gap. These ranged from an international agreement on neutral trade to the prohibition of the export of contraband goods unless title be vested first in the foreign purchaser.

As a result of his crusade to keep the United States out of the next war then brewing in Europe and of the discussion thereby aroused, he was asked by the State Department to prepare a memorandum on neutrality. Many of Mr. Warren's suggested restrictions on so-called neutral rights (such as export of munitions on a cash-and-carry basis, travel of Americans on belligerent vessels, arming of American merchant vessels, financial transactions with belligerents, and so forth) were incorporated in the series of Neutrality Laws enacted in 1935, 1936, 1937, and 1939. But not until November 17, 1941, when war had become a reality in Europe and Pearl Harbor was in the making, were the restrictions of the law of 1939 modified at the insistence of President Roosevelt, and our lot was again thrown in with the Allies.

Sandwiched in the above papers were other contributions, too numerous to mention, on neutrality questions before other organizations, even as late as 1940. And a further digression occurred in 1943 when, in the proceedings of the Society dealing with the punishment of war criminals and in subsequent letters to the New York Times, Mr. Warren strongly urged that the officers of a state guilty of the barbarous erimes against civilization in Europe were not entitled to trial by a court, they already were conclusively proven guilty, and their punishment should be treated as a pure question of policy and expediency to be handled by executive action of the victors, just as the Powers had treated Napoleon.

The final phase of Mr. Warren's life and work was a sort of miscellany screened from the labors of earlier years and the reflections of mellowing age. As by-products came materials for numerous articles, lectures and addresses at universities, Bar Associations, and other bodies in many States. Hardly a year went by that he was not invited to give a course of lectures or deliver an address or prepare a paper. Space does not allow a review of these excursions in legal history, but one can hardly pick up a copy at random (like "The Trumpeters of the Constitution" delivered at the University of Rochester) and read it without a thrill of patriotism at the events portrayed and of admiration for the writer who could breathe life into the dust of history. His last book was $O d d B y$-Ways in American History (1941), recounting some of the "picturesque and unusual episodes" in American history between 1778 and 1840 wherein "we seemed to have slipped for one lawless moment out of the iron rule of cause and effect." And finally there came, surprisingly, a long poem called "Paraphrase of Job's Dark Days"' (1941). 
Charles Warren may be appraised not only by his intellectual attainments, but by his high principles of character. One could not but be impressed by his intellectual honesty and his steadfast search for the truththe "Veritas" of his beloved Alma Mater. Indeed, his innate sense of fairness caused him to present both sides of a controversial question. Although he was endowed with a creative imagination, yet there was a strain of solid practicality running through his nature which kept him aloof from the pitfalls of speculation and sophism. And in his strength of conviction he stood up for views, whether his own or another's, which his acute mind had sifted and found free of dross. Underneath all ran a vein of subtle humor which enlivened his writings and his friendships. Now his clear voice in the pathways of history is still, but the pathways he trod he left forever adorned and endeared.

\section{H. WOOLSEY}

\section{COLLECTIVE SECURTTY AND THE LONDON AGREEMENTS}

At the close of the first World War the words "collective security," "collective responsibility for the maintenance of peace" were words of high hope for the establishment of law and order in a world of states which had hitherto resisted any effective restraints upon their sovereign right to have recourse to war to enforce claims they believed to be just. The principle underlying collective security was simple enough: that the combined forces of the law-abiding states would be so formidable that no state that might otherwise be tempted to defy the law would dare to challenge them. The possibility of organizing the collective forces of the law-abiding states was, perhaps, too easily taken for granted; although under the conditions of the time, with the movement of troops as slow as it then was, there was reason to believe that the formidable array of reserved military strength possessed by the law-abiding states would make it clear to a possible aggressor that it could not hope to win its war in the end. All that was needed was unity among the leading Members of the League of Nations; and these were counted upon to be law-abiding. The participation of the United States in the system was, indeed, important; but even without that, it appeared possible to make it work.

Much the same hope existed when the Charter of the United Nations was signed at San Francisco on June 26, 1945. But this time the machinery of collective security was made more effective, both in respect to decisions in regard to acts of aggression and in respect to combined military action for the enforcement of the law. The assumption of unity on the part of the permanent members of the Security Council, however, soon proved to be unfounded; but even the unforeseen break between East and West might not have proved fatal to the principle of collective security had not the invention of the atomic bomb introduced a new instrument of warfare so devastating in its effects as to give an almost overwhelming advantage to a surprise attack. Hence the need for the organization of defense by alliances and regional groups in which there would be no veto of the Soviet Union, and immediate action could be taken for self-defense under Article 51 of the Charter. 